\title{
NEW DOCUMENTS ON BENITO ARIAS MONTANO (ca 1525-1598) AND POLITICS IN THE NETHERLANDS*
}

\author{
Antonio Dávila Pérez (Cádiz)
}

Benito Arias Montano (ca 1525-1598) set foot in the Netherlands for the first time on 15 May 1568. After a difficult journey across Ireland and England, where he had survived encounters 'civil and uncivil', he arrived at Antwerp in obedience to Philip II's instructions to assist in the process of editing and printing the Biblia Polyglotta or Biblia Regia, on which the publisher Christopher Plantin had already been working for several years. This edition was the product of a desire to provide the 'Christian Republic' with a Bible in the original languages, with text and commentary corrected in accordance with the very latest biblical philology. Arias Montano was then forty-two years old, and although most of his works were still to be written and published, his fame as a reflective and perceptive theologian had already reached the king. Philip therefore entrusted this weighty mission to him, 'as a priest and theologian highly curious and expert in the Holy Scripture and as our servant, [...] and because of our satisfaction concerning your person, talent, letters and Christian fervour.'2 At that time, Arias was a man at the height of social and intellectual success: a knight of the military order of Santiago, Royal Chaplain of Philip II, and now supervisor of the century's most important project in biblical philology.

During the seven years of his sojourn in Antwerp (1568-1575), Arias not only worked as a director of that magnificent Bible in five languages, but also spent his time in countless other official tasks. He

* This research was conducted as part of Research Project HUM2006-05381 of the Spanish Ministry of Education and Science. I am deeply indebted to Jeanine De Landtsheer, Werner Thomas and Enrique Morales for their useful corrections, observations and suggestions.

${ }^{1}$ Benito Arias Montano to Philip II, 6 July 1568, in T. González Carvajal, Elogio histórico del doctor Benito Arias Montano, Memorias de la Real Academia de la Historia 7 (Madrid 1832), 148 (doc. 26).

${ }^{2}$ Instructions to Benito Arias Montano 'as regards the impression of the Bible that was to be made in Antwerp', 25 March 1568 (Spanish draft kept in Archivo General de Simancas E 537, f. 94-95, published by Carvajal, Elogio histórico, 140-144 (doc. 19)). 


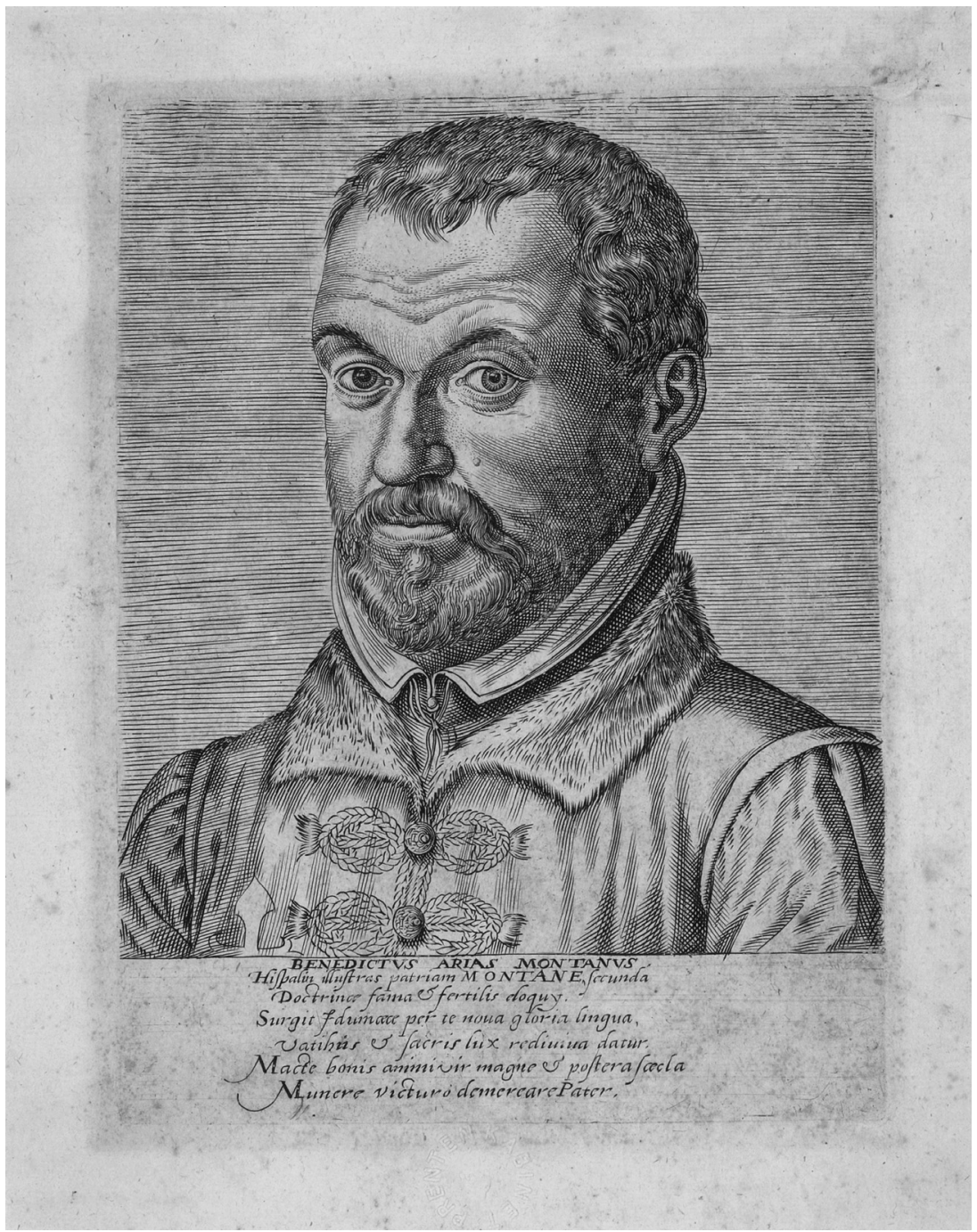

Fig. 11. Anonymous, Portrait of Benito Arias Montano, engraving. Antwerp, Museum Plantin-Moretus / Prentenkabinet, inv.nr. OP 11064 
directed the redaction of the Index of forbidden books in 1570 and of the Index of expurgated books in 1571, bought and collected books and manuscripts for the new royal library of the Escorial, and supervised the administration and printing of the liturgical books (breviaries, missals, books of hours) Plantin produced for the Spanish Crown. On top of this, he worked as a commercial agent for many Spanish friends, sending them books, astronomical instruments, tapestries and so on at the best prices. As far as his humanist interests are concerned, during this period he also managed to write eleven short treatises on biblical history, geography and archaeology, which were to form the Apparatus Sacer, the last volume of the Polyglotta. Besides a treatise on rhetoric in hexameters (Rethoricorum libri quattuor, Antwerp 1575), he translated the Psalms into Latin (Davidis regis ac Prophetae aliorumque sacrorum vatum Psalmi, ibid. 1573), wrote commentaries on the Holy Scripture such as the Commentaria in duodecim prophetas (ibid. 1571), and a theological treatise for students (Dictatum Christianum, ibid. 1575). During holidays Arias Montano could not stop working, but spent long hours in-according to his own words-minor things and hobbies, such as writing Latin poetry, naturally on biblical themes. As a result of this hobby the large collection entitled Humanae salutis monumenta appeared in $1571 .^{3}$ Taking into account this frantic activity, it is not strange that harsh condemnations of sloth and idleness can be found in many of his works: 'Christians were not born to be in idleness, but to serve God and His Republic, each one with what God gave to him', ${ }^{4}$ or 'man is born to work, and birds to fly'. ${ }^{5}$

One of the countless tasks he performed in the Netherlands concerned politics. Nevertheless, the most important epistolary sources for the history of the Revolt have omitted Arias Montano's name. Luis Morales Oliver was the first scholar to study Arias Montano's involvement in the political situation of the Netherlands. His work

\footnotetext{
${ }^{3}$ Besides the works mentioned, Montano published with Plantin poems in elegiac couplets in Virorum doctorum de disciplinis benemeritis effigies XLIIII (1572), Humani generis amatori Deo liberalissimo sacrarum divinarum nuptiarum conventa et acta Christi Iesu Vitae (1573), David, hoc est, virtutis exercitatissimae probatum Deo spectaculum Iesu Christi dignitatis virtutis et efficientiae praenuntiis Sibyllis X (1575).

${ }_{4}^{4}$ Arias Montano to Gabriel de Zayas, 19 August 1575, in Correspondencia del Dr. Benito Arias Montano con Felipe II, el secretario Zayas y otros sugetos desde 1568 hasta 1580, Colección de Documentos inéditos para la Historia de España (Madrid 1842-1914), 41, 323.

${ }^{5}$ Benito Arias Montano, Naturae Historia, prima in magni operis corpore pars (Antwerp 1601), 2.
} 
Arias Montano y la politica de Felipe II en Flandes is based on several published and unpublished documents and sheds much light on this subject. Morales Oliver echoes a dialogue between Aristotle and Alexander the Great about the counsellors of princes: they are like eyes and they have to make judgements on the present, the past and the future, in the same way that sight extends in all directions. ${ }^{6}$ Philip II entrusted a number of remarkable men throughout his Monarchy with the task of sending him secret reports, and after Morales Oliver's study it is beyond all doubt that during his sojourn in the Netherlands, Arias Montano operated as one of these agents and secret counsellors to the king. Since then, however, little has been published about his political position and his real influence during the Dutch Revolt, despite the extent of the recent literature on Arias Montano. Only Herta Schubart, ${ }^{7}$ and later Ben Rekers, ${ }^{8}$ have studied this aspect of his career, and they closely follow Morales Oliver's main arguments. It is not a commonplace when J. Gil writes in his book Arias Montano. Bienes $y$ Herederos that very much is known about Montano, but at the same time very little. My aim is to complete what is known about the role Montano played in the conflict in the Netherlands. The main source of this study will be primary documents, above all previously unpublished private correspondence.

During the government of Alva (1568-1573):

THE UNPUBlished CORRESPONDENCE BETWEen ARIas Montano AND the House of Alva

Let us first summarize what is already known about Arias Montano in connection with the Duke of Alva. The six and a half years that Alva stayed in Flanders can be divided into three main periods: violent repression and the first war against the Orangists (1567-1568); truce (1569-1572); and the second war against the Orangists (1572-1573). At the beginning of his sojourn in Antwerp, the relationship between Alva and the Spanish theologian was close to friendship. Alva took

\footnotetext{
${ }^{6}$ See L. Morales Oliver, Arias Montano y la política de Felipe II en Flandes (Madrid 1927), 107-108.

7 H. Schubart, 'Arias Montano y el Duque de Alba en los Países Bajos', in Renuevos de Cruz y Raya 4 (Santiago de Chile-Madrid 1962), 9-73.

${ }^{8}$ B. Rekers, Arias Montano (Madrid 1973).
} 
an interest in Arias Montano as the King's Chaplain and the supervisor of the edition of the Polyglot. Philip II asked Alva to offer Arias Montano 'the warmth and the favour and the authority necessary to accomplish his mission'. ${ }^{9}$ Very soon Alva himself appreciated his rich conversation and deep wisdom. ${ }^{10}$ As for Montano, at the beginning of his sojourn in the Netherlands, he obviously, like the rest of the Spaniards, valued the efficacy of Alva, whose military skills had stopped the progress of Protestantism in the Netherlands with a clear victory over the rebels in 1568. Obviously, Arias Montano, a leading Catholic reformer, was appalled by the events of the first revolt (1566). He was deeply impressed by the destruction of religious objects and representations and the setting fire to abbeys, in particular the one 'called the Dunes, that was the richest in good ancient books [...], reason why I felt deep pain because of my interest in good studies.' ${ }^{11}$

One should also emphasize that from 1568, when Alva defeated the first revolt, to 1572, when the second revolt began, Montano collaborated closely with Alva's religious policy. In order to defend Catholicism by any means, the two of them were instrumental in producing the Index expurgatorius librorum qui hoc saeculo prodierunt (Antwerp 1571). The redaction of this list was ordered by the duke and executed by Montano. ${ }^{12}$ In his first report as a counsellor, written in February 1571, Montano supported the severity of Alva's repression, which he

9 Philip II to Alva, 25 March 1568, in Carvajal, Elogio histórico, 114 (doc. 20).

10 'The Duke enjoys his company very much, and they discuss thousands of excellent matters', letter of Juan de Albornoz to Zayas, 29 June 1569, in Carvajal, Elogio histórico, 132 (doc. 22).

11 Arias Montano to Philip II, 6 July 1568, in Carvajal, Elogio histórico, 149 (doc. 149). Juan de Albornoz tells Gabriel de Zayas a curious anecdote that shows the close sympathy between Alva and Montano: 'It was necessary to send ten companies of Spaniards to Louvain for some time, because those people are rather difficult. Representatives from the University, among them Arias, came to beg his Excellency [Alva] to withdraw his troops, a very erudite doctor addressed him with a very long and eloquent speech. The Duke, who had been in bed for twenty days, this being the first day that he had been out to Mass, had to stand throughout this long discourse. When it was finished, Arias Montano was moved to say: "Lord, since I also come from the University, they entrusted me to ask my colleague to give his speech again, in case your excellency did not admit our request." The duke could not help laughing'; Juan de Albornoz to Gabriel de Zayas, 25 September 1569, in Carvajal, Elogio histórico, 132 (doc. 22).

12 See my article 'La censura erasmista en el Índice Expurgatorio de 1571 a través de los documentos de Benito Arias Montano', in M. Pérez González (ed.), Actas del Congreso Internacional sobre Humanismo y Renacimiento (León, 4-8 de junio de 1996) (León 1998), 1, 303-310. 
considered necessary to stop any kind of heresy; the royal chaplain furthermore attacked the customs of the Flemish people, who were very fond of masquerades, drinking, and celebrating banquets. ${ }^{13}$ In this context, it is not strange that when the Duke of Alva asked King Philip for permission to retire, in the Summer of 1571, Arias was one of the voices flatly opposed to that decision. ${ }^{14}$ Montano's admiration for the duke reached its height when the humanist drew the design for a bronze statue of Alva that was placed in the citadel of Antwerp, and provided the following inscription: ${ }^{15}$

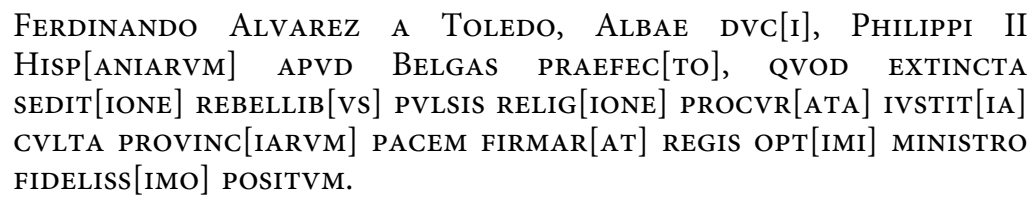

Erected in honour of Fernando Álvarez de Toledo, the most loyal minister of the most excellent King, Duke of Alva, prefect of Philip II of Spain in Belgium, because he strengthened the peace of the Provinces by extinguishing a revolt, expelling rebels, aiding religion and cultivating justice.

The first evidence that Montano's opinion of Alva's policy was beginning to change comes from the second part of 1571, when he censured a tax imposed by Alva to cover the huge wages of his army. The Tenth Penny was an annual tax that burdened every sale of chattels with a

${ }_{13}$ Arias Montano to Gabriel de Zayas, 5 February 1571, in Correspondencia del Dr. Benito Arias Montano...desde 1568 hasta 1580, Colección de Documentos inéditos 41, 200-234 (226-227). This is a long report of twenty-five pages written by Montano at the request of the king's secretary. It is important to say that Arias informed Juan de Albornoz, Alva's secretary, that the king was very interested to read this report: Arias Montano to Juan de Albornoz, 18 April 1571, in Archivo de la Casa de Alva (Madrid, Palacio de Liria, C. 28/179).

14 Arias Montano to Juan de Ovando, 10 October 1571, in M. Jiménez de la Espada, El Código Ovandino (Madrid 1891), text quoted by Rekers, Arias Montano, 27: 'I feel deep sorrow about the changes I have understood there are in the governance of this land; for I have seen how things have passed off so far and to which point they have come [...] and since I came to know in secrecy that the permission the Duke of Alva had asked had been granted to him, I feel deep grief.'

${ }_{15}$ The sculptor was Jacques Jonghelinck, who also worked for Alva in other iconographical projects. The statue was removed in 1574 as a consequence of the damnatio memoriae. This monument was welcomed neither in Antwerp nor in the Spanish court. We know the statue and the inscription thanks to an engraving by Paludanus; on this subject, see Morales Oliver, Arias Montano y la politica, 136-144; J. Alba y Berwick, Discurso de entrada en la Academia de la Historia (Madrid 1919) and Schubart, 'Arias Montano y el Duque de Alba', 27-41. 
ten percent surcharge. Arias Montano dared to send the king, probably without informing Alva, a few lines of a letter written by the Lord Sheriff of Antwerp, in which he complains of the harm the new tax was doing among the population of the city. King Philip's doubtful answer is to be found in an unpublished document preserved in Simancas (Valladolid) that has an obvious historical value: 'This subject must be considered carefully, because, on the one hand, we have what they write, and on the other, what is there must be supported with Flemish money, since it is impossible with Spanish money.' ${ }^{16}$

The clearest change in Montano's political position happened in the course of 1572: on 26 April he had to leave the Netherlands for Rome, in order to obtain papal approval for the Polyglot Bible. During the five months of his absence, ${ }^{17}$ the general rising and the revolt of 1572 took place. When Montano returned to the Low Countries on 1 December, ${ }^{18}$ he expressed deep pain at the situation he found: 'It is a great ruin what I have found here, and my heart is broken since I have seen so much change.' ${ }^{\prime} 9$

Once the work on the Bible was over, the King asked him to remain in the Netherlands 'above all because there are matters to my service that are entrusted to you. ${ }^{20}$ From this period several documents are preserved in which Montano played a more active role as royal counsellor. ${ }^{21}$ It was during this time that he took a more active part in politics, and his contact with the king was direct. At the beginning of 1573 he protested against Alva's methods of terror, and recommended ways of pacification in order to 'recover the hearts' of Philip II's vassals

16 The lord sheriff of Antwerp to Arias Montano, 26 August 1571, manuscript copy kept in Archivo General de Simancas E, 546/25.

${ }_{17} \mathrm{He}$ left Rome at the beginning of October; see a letter from Juan de Zúñiga to Philip II, 13 October 1572, in Carvajal, Elogio histórico, 166 (doc. 48).

18 Arias Montano to Philip II, 18 December 1572, in Correspondencia del Dr. Benito Arias Montano... desde 1568 hasta 1580, Colección de Documentos inéditos 41, 273280.

19 Arias Montano to Juan de Ovando, 20 January 1573, in M. Jiménez de la Espada, 'Correspondencia del Doctor Benito Arias Montano con el licenciado Juan de Ovando', in Boletín de la Real Academia de la Historia 19 (1891), 497.

20 'He acordado que por agora os quedéis y residáis en ellos, mayormente que con esto ocurren cosas de mi servicio que ahí se os encomiendan', Philip II to Arias Montano, 24 February 1573, in Carvajal, Elogio histórico, 167-168 (doc. 52).

21 There are three reports or 'advertimientos' addressed to the king (Archivo General de Simancas E, 583 and 983, and Instituto de Valencia de Don Juan 35/38); two letters to the king (Archivo General de Simancas, Estado, 167; Universidad de Sevilla Ms. 333-166). More references in Morales Oliver, Arias Montano y la política, 13. 
in the Netherlands. ${ }^{22}$ And again, in the middle of 1573, he added new criticisms, above all concerning the attitude of Spanish soldiers: 'The arrogance of our nation is unbearable. ${ }^{23}$ According to him, the ideal solution was a general pardon, in opposition to the system of severity applied by Alva. Montano's view of the Revolt of the Netherlands changed even with regard to the character of the native people: in contrast with his former tone of irritation, when speaking of the feasts and the masquerades that the Flemings were so fond of, ${ }^{24}$ he now compared their banquets and carnivals with those of the ancient Greeks. ${ }^{25}$

What has been said above on Montano and Alva is a synthesis of previous scholarship on this subject. According to the main documents published and studied by Morales Oliver, it seems obvious that Montano's thinking shifted from support of Alva's policy to urgently requesting a change of methods. I have recently had access to the original manuscripts of eighteen letters, as yet unpublished, written by Arias Montano and preserved in the archive of the House of Alva. This correspondence begins on 7 January 1569 and runs to 4 January 1574, and contains two letters to Alva, one to Alva's steward, Juan Moreno, and sixteen to his secretary, Juan de Albornoz. It is now time to consider what the correspondence preserved by the House of Alva clarifies about two matters previously obscure: firstly, the causes of Montano's change of view, and secondly, how this change affected the relationship between the governor and the humanist.

22 Arias Montano to Gabriel de Zayas, 27 February 1573, in Correspondencia del Dr. Benito Arias Montano...desde 1568 hasta 1580, Colección de Documentos inéditos 41, 289-290.

${ }_{23}$ 'The arrogance of our nation in unbearable [...] and I am not speaking about the main ministers of our nation, but about the secondary and minor ones, who indeed use too much haughtiness towards others. This sours their attitude towards us, disrupting both the good course of affairs and the aide to business [...]. These states must never be granted to remain without Spanish soldiers, for this constraint is necessary for the nobles and for the riotous and rioters. Nevertheless, these soldiers must be in a specific amount and kept in hand [...] and there they must be well deployed and sorted out and disciplined.' Arias Montano to Gabriel de Zayas, (May 1573), in Correspondencia del Dr. Benito Arias Montano... desde 1568 hasta 1580, Colección de Documentos inéditos 37, 89.

${ }_{24}$ Arias Montano to Gabriel de Zayas, 5 February 1571, in Correspondencia del Dr. Benito Arias Montano... desde 1568 hasta 1580, Colección de Documentos inéditos $41,226-227$.

${ }_{25}$ Arias Montano to Gabriel de Zayas, November 1573, in Morales Oliver, Arias Montano y la política, 268. 
These letters show that Montano was asked time and again to promote the private interests of his acquaintances, friends and intimates. In a letter to Zayas he complained that, as royal servant, more and more of his time was taken up with promoting the private interests of others. ${ }^{26}$ During his sojourn in the Netherlands, he acted as a commissioner and an intelligencer for Philip II, but also as a private adviser to Alva, the king's governor general in the Netherlands. In this situation, appeals for intercession came either from Spain, as we have seen, or from Italy or the Netherlands. At the beginning of 1569, Arias asked the duke to give one of his soldiers permission to return to Spain in order to take care of a farm left him by his uncle, a distant relative of Montano. ${ }^{27}$ Four months later, he applied for the fortress of Pavía on behalf of Rafael Manrique, a former schoolmate and childhood friend, and brother of the Head Chaplain Luis Manrique, to whom Arias was very close. ${ }^{28}$ In April 1573, Montano visited Alva on the campaign at Nijmegen, asking him for help and intercession on behalf of Ascanius Caffarelus, a knight of the same order as Montano. Caffarelus wanted to collect a huge debt from Claudius Vandenberghe, 'Dean or I do not know what dignity he has in Lille. ${ }^{.29}$ During the revolt of 1572 , Plantin did not hesitate to make use of Arias Montano's name to persuade the Duke of Alva to have the soldiers billeted on him moved elsewhere. ${ }^{30}$ When Montano learnt that he had permission to leave the Netherlands in the middle of 1574, his first reaction was anxiety that his return to Spain would cause among many people in the Netherlands, who appreciated his influence and mediations: 'They all rise in joy upon hearing Montano's name as the benefactor of the country and its citizens. ${ }^{31}$

\footnotetext{
${ }^{26}$ Arias Montano to Gabriel de Zayas, 4 January 1579, in Correspondencia del Dr. Benito Arias Montano...desde 1568 hasta 1580, Colección de Documentos inéditos 41, 373-378.

${ }_{27}$ Arias Montano to Juan de Albornoz, 7 January 1569, original in Archivo de la Casa de Alba (Madrid), C. 28/168.

${ }_{28}$ Arias Montano to Juan de Albornoz, 22 May 1569, original in Archivo de la Casa de Alba, C. 28/171.

${ }_{29}$ Arias Montano to Juan de Albornoz, 23 April 1573, original in Archivo de la Casa de Alba, C. 28/183.

${ }^{30}$ Cf. A. Dávila Pérez (ed.), Benito Arias Montano. Correspondencia conservada en el Museo Plantin-Moretus de Amberes, Palmyrenus. Colección de textos y estudios humanísticos, serie textos 3, 1-2, 2 vols (Alcañiz-Madrid 2002), [72 06 09].

31 'Ad nomen Montani tamquam benefactoris patriae et ciuium omnes assurgunt et laetantur.' Arias Montano to Gabriel de Zayas, 18 April 1574, in Correspondencia
} 
From these unpublished letters preserved by the House of Alva, we have evidence of the ways in which Montano took part in the politics of the Netherlands. One of these was the recommendation of suitable local persons to civil and ecclesiastical posts. In 1571 he put forward the name of Franciscus Nansius for the post of magistrate in Bruges: Nansius was a friend of Justus Lipsius and Abraham Ortelius, both closely connected to Montano. ${ }^{32}$

Franciscus Nansius surpasses everyone in integrity and excels in erudition; he is a man of means, and I am convinced that he will do an excellent job. Everything incites me to recommend him and to consider him an appropriate candidate for this task, especially since I am well aware of the kind of men a government needs for its administration. ${ }^{33}$

Arias Montano was able to win the sympathy of the people. He even boasted that local inhabitants trusted him more than any other Spaniard: 'since I am an impartial and quiet person, they dare to confess to me their concepts, their imaginations and their suspicions. ${ }^{34}$ When he recommends the name of Nansius to Albornoz, he puts in practice his own principle of choosing local inhabitants for political and religious posts: 'one of the reasons why the inhabitants of the Low Countries are unhappy is because they think they are excluded from taking part in the government. ${ }^{35}$ The persons selected, who belonged to the culturally advanced elite of the Netherlands, were surely introduced to him by his friends there. The role Montano played as a link between the Spanish governor and the local upper classes also affected the world of arts: in his letters to Albornoz and Alva, he acts as a mediator in the contacts between Alva and, among others, the botanist Rember-

del Dr. Benito Arias Montano... desde 1568 hasta 1580, Colección de Documentos inéditos 41, 304-305.

32 Arias Montano to Juan de Albornoz, 8 August 1571, original in Archivo de la Casa de Alba (Madrid), C 28/168.

${ }_{33}$ Arias Montano to Juan de Albornoz, 8 August 1571, original in Archivo de la Casa de Alba (Madrid), C. 28-173. In September 1575, Franciscus Nansius thanks Montano for his recommendation to the post of burgomaster in Bruges (Plantin to Montano, 18 September 1575, in Dávila, Benito Arias Montano. Correspondencia, 75 0918.

${ }^{34}$ Arias Montano to Gabriel de Zayas, May 1573 (?), in Correspondencia del Dr. Benito Arias Montano...desde 1568 hasta 1580, Colección de Documentos inéditos 37, 90.

35 Arias Montano to Gabriel de Zayas, May 1573 (?), in Correspondencia del Dr. Benito Arias Montano... desde 1568 hasta 1580, Colección de Documentos inéditos 37, 95-97. 
tus Dodonaeus, ${ }^{36}$ the sculptor Jacques Jonghelinck, ${ }^{37}$ the engraver Guilielmus Paludanus, ${ }^{38}$ and the physician and humanist Johannes Goropius Becanus. ${ }^{39}$

The House of Alva correspondence confirms that Montano operated as the director of Alva's religious policy, above all the repression of Protestantism in the books and pamphlets published in the Low Countries. The king was very satisfied with the results of his contribution to the Index prohibitorius of 1570 and the Index expurgatorius of 1571, and he explicitly told the duke to 'make use of Montano and provide him with similar tasks to serve God and the King. ${ }^{40}$ Once the index was finished, in a letter signed 22 August 1571, Montano urged the Duke of Alva to allocate a place for the building of the prototypographia regia, in order to facilitate Plantin's job of checking the orthodoxy of the books published in the Netherlands. He suggested a plot next to Paludanus's house, where the Jesuits also wanted to build a new school. ${ }^{41}$ The new building, where Plantin could also install his presses, was a way of compensating the printer for a post without remuneration. The theologian used strong arguments to persuade Alva: 'I think that His Majesty will be very satisfied with this matter, as he was with everything that has been done regarding doctrine and books. ${ }^{42}$ Nevertheless, these plans were never carried out, due to lack of money.

In 1572, there was a profound silence in the correspondence between Montano and Alva, obviously because of the former's journey

\footnotetext{
${ }^{36}$ Arias Montano to Juan de Albornoz, 14 February 1569, original in Archivo de la Casa de Alba (Madrid), C. 28/169.

${ }_{37}$ Arias Montano to the Duke of Alva, 11 December 1573, original in Archivo de Zabálburu (Madrid), C. 212/16.

${ }^{38}$ Arias Montano to Juan de Albornoz, 8 August 1571, original in Archivo de la Casa de Alba (Palacio de Liria, Madrid), C. 28/168; and Arias Montano to Juan de Albornoz, 2 October 1571, Archivo de la Casa de Alba (Palacio de Liria, Madrid), C. $28 / 176$.

${ }_{39}$ Arias Montano to Juan de Albornoz, 14 January 1571, original in Archivo de la Casa de Alba (Palacio de Liria, Madrid), C. 28/172.

${ }^{40}$ Philip II to the Duke of Alva, 22 March 1570, text quoted by Rekers, Arias Montano, 26.

${ }^{41}$ See A. Dávila Pérez, 'La correspondencia inédita de B. Arias Montano: nuevas prospecciones y estudio', in Benito Arias Montano y los humanistas de su tiempo, J.M. Maestre Maestre, E. Sánchez Salor, M.A. Díaz Gito, L. Charlo Brea, and P.J. Galán Sánchez (eds.), 2 vols (Mérida 2006), 1, 75-78.

${ }^{42}$ Arias Montano to Duque of Alva, 22 August 1571, original in Archivo de la Casa de Alba (Palacio de Liria, Madrid), C. 28/174.
} 
to Rome and the duke's military campaign during this period. But the unpublished letters preserved from after that year are worth careful examination. Although the tone of these eight letters and their main subjects (private matters, intercession in favour of artists, clergymen and humanists of the Southern Netherlands) do not show any change in the quality of the relationship between the humanist and the governor, some passages indicate that Montano's views were shifting, as has been outlined above.

It is, however, worthwhile to consider a quite interesting letter shedding new light on the subject at hand: on 28 March 1573, just in the period when most scholars speak of a confrontation between Alva and Montano, the theologian writes in terms of complete submission to the governor:

If the Duke would have to stay in these States a long time, I would easily accept any task because of his benevolence and warmth. If, as you told me, he must leave for Spain, I hope that he will take me away from here in order to serve him there.

In this letter, Arias Montano severely attacked the attitude of the Dutch rebels, 'with whom the Devil easily negotiates.' As far as the methods of war were concerned, he recommended trying to defeat them by fair means first, but 'when it is necessary to use force, we must do so bravely in order to bring them back to the right track, which they ran away from. ${ }^{43}$ Hence this document casts doubt on the supposed friction between Alva and Montano from 1572 onwards. According to Montano's extant reports to King Philip, so brilliantly studied by Morales Oliver, there was a world of difference in their opinions in 1573. Meanwhile, as the unpublished letters examined here have shown, the theologian could write letters of complete submission to the person and the political decisions of the duke. The subjective reasons for Montano's shift from the defence of Alva's policy to positions closer to the local point of view will be studied later, after our analysis of his political activities during the gentler regime of the new governor, Luis de Requesens. But taking into account the correspondence preserved in the archive of the House of Alva, it must be admitted that, although Montano changed his view of the turmoil in the Low Countries, as other counsellors and even King Philip did from 1572

\footnotetext{
43 Arias Montano to Juan de Albornoz, 28 March 1573, original in Archivo de la Casa de Alba (Madrid), C. 28-181.
} 
onwards, he did not withdraw his support from Alva. Moreover, even prior to the new governor's arrival, he kept serving him in the way he had since the first years of his sojourn in the Netherlands. The most reasonable conclusion we can come to is to stress the great political and social skills of Montano, who, from his first youth, always showed a great talent to serve powerful men and to maintain these relationships for a long time.

DuRING THE GOVERNMENT OF LUIS DE REQUeSENS (1573-1575): THE correspondence between Arias Montano and Juan de Zúñiga

The new governor, Luis de Requesens, arrived in Brussels on 17 November 1573. On 29 November he was sworn in as Alva's successor. During this second period (1573-1575) Arias Montano played a more remarkable political role. Once he had obtained papal approbation for the Polyglot Bible at the end of 1572, his mission as Royal Commissioner came to an end. Yet, in his reports of mid-1573, the king noted an exceptional ability to obtain direct information from the local governing classes, among whom Arias moved easily. On 17 June 1573, Philip II had already informed Alva of his replacement as governor, since measures other than severity were needed to solve the conflict in the Netherlands. ${ }^{44}$ One month later, the king asked Montano to carry out new tasks as a secret counsellor:

What His Majesty wants and in which you shall do him great service is that you hear from the locals themselves [...] what suitable solutions might be chosen $[\ldots]$ and that they say by what means they can be achieved [...]. His Majesty has a truly paternal desire for a solution, as you must make them understand everywhere and at every opportunity. ${ }^{45}$

Thus, Montano's political influence grew from the very beginning of Requesens's government. Alva stayed in Brussels until 18 December and during this month of overlap, he obviously advised and informed

${ }^{44}$ Philip II to the Duke of Alva, 17 June 1573, in L.P. Gachard, Correspondance de Philippe II sur les affaires des Pays-Bas publiée d'après les originaux conservés dans les Archives royales de Simancas, 5 vols (Brussels 1848-1936), 2, no. 127, text quoted by Rekers, Arias Montano, 38.

${ }^{45}$ Gabriel de Zayas to Arias Montano, 17 June 1573, in Correspondencia del Dr. Benito Arias Montano... desde 1568 hasta 1580, Colección de Documentos inéditos 41, 292. 
the new governor, and even tried to persuade him to maintain his own harsh measures. But we know that Montano, obeying the King's instructions, was also very close to Requesens and probably recommended a softer policy:

[Montano] was in Brussels when the High Commander arrived and he spoke with him four times, for three hours each time, and sometimes with caution for they knew very well that there were spies and other people listening. ${ }^{46}$

Montano's sympathy for the people in the Low Countries had increased. According to him, the best criterion to decide which political resolution was good or bad was the vox populi: 'In the meantime there is a touchstone on which the metal of each reasoning can be tested, and this is the common people's current voice. When all claim that a measure is a humiliation, it is truly so. ${ }^{37}$ This is not the superficial judgment of a foreigner. In this assertion he shows his refined ability to analyse the Revolt of the Netherlands. Neither the opinion nor the interests of the inhabitants had ever been taken into account by their rulers, who were always seen as foreigners. Montano made an important effort to gain their trust. Hence it is logical that he continued to recommend local people for the main ecclesiastical and political posts: 'The High Commander does me honour and favour and tells me, when we are together, some things about which I say what I dispassionately feel and think, and beyond this I give him news about some clergymen and laymen who in my opinion are perfect to serve. ${ }^{38}$

As for the relationship between Requesens and Montano, we can confirm that it was forged long before 1573. In 1567 Luis de Requesens, then ambassador of Philip II in Rome, succeeded in obtaining a pension for Arias Montano upon his return from the Council of Trent. ${ }^{49}$ In May 1572, the Spanish theologian stopped in Milan while on his way to Rome to obtain approbation for the Polyglot Bible. At this time Requesens, also a knight of the Order of Santiago, was governor

${ }^{46}$ Gabriel de Zayas to Philip II, 29 November 1573, in Morales Oliver, Arias Montano y la política, 315-318.

47 Arias Montano to Gabriel de Zayas, November 1573, in Morales Oliver, Arias Montano y la política, 327-328.

48 Arias Montano to Gabriel de Zayas, 18 April 1574, in Correspondencia del Dr. Benito Arias Montano... desde 1568 hasta 1580, Colección de Documentos inéditos $41,303$.

${ }^{49}$ See Carvajal, Elogio histórico, 136-137 (docs 8, 9, 10, 11, and 12). 
of that region: on 21 May he wrote to his brother, Juan de Zúñiga, that he considered Montano a good friend. ${ }^{50}$

We can now turn to analyzing two documents that shed some light on this period of Montano's life, namely to two letters from 1573 that he addressed to Juan de Zúñiga, at that time Philip II's ambassador in Rome. On 30 May, he wrote to Zúñiga a few favourable words about Alva. As for the miseries and war of Flanders 'the duke does what he can, and it is more than anybody could expect considering his age and isolation [...]. Day and night he thinks of nothing but what is convenient to the well-being of these States without respect to his own health.' Yet, in the postscript of the same letter, he seemed to have the secret information that Requesens had been chosen to replace Alva: 'I am glad to have received a letter of 17 May from the High Commander, and I would be happier if what he said in that letter and what they wrote to me from Spain were to happen. ${ }^{51}$ Once again we can see the political skill of Montano, who is able to survive successfully in the transition between two completely opposite regimes.

In spite of this deep involvement in political matters, Montano's letter to Zúñiga mainly contains passages showing an eagerness to obtain permission to leave the Netherlands in the middle of 1573 . He knew that Zúñiga had remarkable influence with King Philip. Thanks to him, the latter had granted Arias a large amount of money that had long been requested to pay the debts incurred for the Polyglot Bible. Montano wrote that Zúñiga was 'the most important voice he had in this business', ${ }^{52}$ and made use of those letters to beg the ambassador to get the king's permission for him to retire to the Peña de Aracena, his place of meditation in the South of Spain:

I have never ever asked a thing for myself nor made the gentlemen I know at Court spend their time in asking anything for me beyond a place of retirement where I could end my life in study. ${ }^{53}[\ldots]$ Your Highness would help me in asking His Majesty a very great favour for me

\footnotetext{
${ }^{50}$ Archivo histórico de Valencia de Don Juan 1/6, quoted by Morales Oliver, Arias Montano y la política, 236-237.

${ }^{51}$ Arias Montano to Juan de Zúñiga, 30 May 1573, original in Pierpont Morgan Library (New York), RS, 1522, no. 454. This letter and the next one were recently edited by I. Lerner, 'Dos cartas inéditas de Benito Arias Montano en la Morgan Library and Museum', in Voz y letra 20.1 (2009), 129-140.

${ }_{52}$ Arias Montano to Juan de Zúñiga, 28 June 1573, original in Pierpont Morgan Library (New York), RS, 1522, no. 455.

${ }_{53}$ Arias Montano to Juan de Zúñiga, 28 June 1573, original in Pierpont Morgan Library (New York), RS, 1522, no. 455.
} 
which I hope shall be useful for our fellow men and of no expense to His Majesty, and that is, permission to retire in some seclusion and spend the rest of my life there. ${ }^{54}$

These pleas, certainly, reached the king. After Montano's return to Antwerp, in November of 1572, Zúñiga wrote to Philip as follows:

It grieves [Montano] very much that Your Majesty charges him with business outside his profession and it seems to him that if Your Majesty would be kind enough to give him permission to retire he could serve the Church and Your Majesty very much by writing, and that the ones who have seen his works and understand how useful they are repeatedly put in his mind that he should continue writing. ${ }^{55}$

These letters between Arias and the Spanish ambassador in Rome open a new field of research into the relationship between Montano and the Zuñiga family, two members of which were closely connected to him during their most important periods of power. But not much has been preserved from the surely huge correspondence between these three celebrities of the late sixteenth century. ${ }^{56}$

In August 1574, Philip II finally decided that Montano should end his stay in the Netherlands and return to Spain to assume another official task, the cataloguing of the new library of the Escorial. In the spring of 1575 Arias left the Netherlands and went to Rome, where he stayed for over a year. According to the new documents studied here, the main aspiration of Montano from 1573 onwards was to be discharged from his duties as Royal Chaplain. Although his influence during Requesens's regime became even more important, Montano's letters to Zúñiga show a man deeply disillusioned with public life.

After Arias Montano's departure from Antwerp (1576-1598): THE IMPORTANT ROLE OF LUIS PÉREZ AS AN INFORMANT

After his departure from Antwerp, Montano always kept up to date with what was going on in the Netherlands. Although his influence

\footnotetext{
${ }^{54}$ Arias Montano to Juan de Zúñiga, 30 May 1573, original in Pierpont Morgan Library (New York), RS, 1522, no. 454.

${ }^{55}$ Juan de Zúñiga to Philip II, 13 October 1572, in Carvajal, Elogio histórico, 166 (doc. 48).

56 Two more letters from Arias Montano to Juan de Zúñiga survive. The originals, very damaged, are kept in the Spanish Ministery of Foreign Affairs, Leg. 14 (nos. 371 and 372) and are dated 15 September 1577 and 17 October 1577.
} 
on events was obviously lessened, Montano received reports from his friends in the Netherlands and forwarded these to the King. Let us see who was working for Montano as his eyes in the Netherlands after he had returned to Spain. Hitherto two names are known as his informants: the printer Christopher Plantin and Laevinus Torrentius, second bishop of Antwerp. In the following lines I would like to present a previously unknown informant, in my opinion as important as the former two.

The members of Plantin's house called Montano their optimus patronus for many reasons: by means of his profound influence on King Philip, he obtained disbursal of payments to the printing house, always delayed, from the court of Madrid, and many profitable contracts such as the liturgical books (breviaries and missals) and even the post of proto-typographer for Plantin, which made all the important printers of the Netherlands subordinate to him. Plantin had been providing Montano with information since the period of his stay in Antwerp, but the passages describing the course of the war are longer and more frequent in the correspondence between the humanist and the printer after Montano's departure. In Plantin's letters we can follow the most relevant events of the Revolt of the Netherlands from the printer's particular point of view: the general rising and revolt of 1572 is described in detail in the letters from Plantin to Montano, who was in Rome at that time. ${ }^{57}$ The event that had the most terrible effect on Plantin's Officina was the so-called Spanish Fury of Antwerp, at the end of 1576, when the Spanish troops from the citadel and the mutineers from the surrounding towns fell upon the city, drove out the troops of the States General, and plundered and murdered for days. The horror of the event stopped Plantin's correspondence, among other causes because of the troubles of dispatching letters. Johannes Moretus, Plantin's son-in-law, writes that the city of Antwerp had been turned to ash (concremata) and deeply afflicted (afflicta), and informs Montano on Luis Pérez's crucial role as a protector and patronus during those terrible days. ${ }^{58}$ In 1578 Plantin sends Montano his last letter with clearly political contents: the printer, always from his personal point of view but also with sharp-wittedness, analyses the latest events in his home

${ }^{57}$ See Dávila, Benito Arias Montano. Correspondencia, [72 06 09], 7206 21, [72 07 16], [72 $\left.07 \begin{array}{llll}19-72 & 07 & 25\end{array}\right]$, [72 08 07-72 08 22], 7208 29, and [72 11 01].

${ }_{58}$ See Dávila, Benito Arias Montano. Correspondencia, [76 12 01-76 12 22]. 
town, harshly criticizing the patriotic front and its activists, from the lower classes-now extremely disciplined-up to the highest social spheres; at the end of the letter he even vents a sort of criticism against the Spanish Governor, Don Juan of Austria. ${ }^{59}$ This is, as we have said, the most political letter exchanged between Plantin and Montano. From this point onwards, most of Plantin's references to the political situation lack concreteness and blur into words of spiritual feeling and resignation. ${ }^{60}$ Plantin's reports lack any philosophical stance or general principle in judging the facts, containing only a religious tone of resignation. There is no clue as to whether Montano forwarded Plantin's reports to the Spanish Court, as he did those of other informants in the Netherlands. Plantin always made references to other informants who could provide Arias Montano with detailed reports of the course of the war. He himself just described the terrible consequences of the war to his family and business, and addressed Montano as a protector or patronus who could help them materially and spiritually.

The second well-known reporter of Arias Montano is Laevinus Torrentius (Ghent, 1525-Antwerp, 1595), who was enthroned bishop of Antwerp in 1587, but who had been well acquainted with the Spanish theologian for many years. Arias himself recommended him to this see in May 1576. As we see, there is a relationship of gratitude and also patronage between this informant and Montano. Placing his friends in the most important ecclesiastical and civil posts was the only way for him to retain influence in the Netherlands after his return to Spain:

Having heard that two bishops have passed away in Flanders, Jansenius of Ghent and Sonnius of Antwerp [...] I wanted Your Majesty to have good and certain information about many suitable people to choose for those ministries and other singular ones, and mainly for the church of Antwerp, which is of great importance to serve God and Your Majesty [...]. When I was there shortly before I left, the High Commander, God rest his soul, asked me for a list of clergymen and laymen I knew [...]. The first clergyman I mentioned was Dr Laevinus Torrentius [...] and I declared to know him from conversations and talks [...] throughout seven whole years, and not to have seen anywhere in the Low Countries, Italy or Rome a clergyman more appropriate as to his learning, his conscience and his negotiating skills. ${ }^{61}$

${ }^{59}$ Cf. Dávila, Benito Arias Montano. Correspondencia, 780700.

${ }^{60}$ See Dávila, Benito Arias Montano. Correspondencia, 7902 04, [88 08 27], and

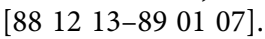

${ }_{61}$ Arias Montano to Philip II, 17 May 1576, in Correspondencia del Dr. Benito Arias Montano... desde 1568 hasta 1580, Colección de Documentos inéditos 41, 339. 
It is quite striking that this letter of recommendation was written in May 1576, that is, still before the death of Franciscus Sonnius, the preceding bishop ( $\dagger$ June 1576). Plantin himself wrote to Montano at the beginning of June that Sonnius was very ill, without any hope for recovery. Montano was in Rome and seemed to be in a hurry to put forward his candidate for the important see of Antwerp. And he succeeded because of his extreme diligence. Torrentius never hid the fact that Montano's influence was conclusive for his appointment as bishop of Antwerp. ${ }^{62}$

The surviving correspondence between Torrentius and Montano ${ }^{63}$ runs from 15 July 1584 to 13 February 1595 . These letters exceed a mere private correspondence: they are written as complete reports on the political situation in the Netherlands. In these increasingly pessimistic reports, Torrentius not only relates military events: he analyses the situation, judges the agents of the Revolt, and proposes solutions to restore Catholicism in the Netherlands. ${ }^{64}$ He mainly argues for peace in his letters. As long as the war continued, the Netherlands would be a ruin. According to his idealistic point of view, two matters should be of overriding importance in the negotiations of peace with the rebel provinces: the restoration of the monarch's authority and care for the Catholics of Holland. Protestants would be progressively converted. ${ }^{65}$ As for the centralizing policy of Philip II, the bishop dared to ask for a more independent organization of the Netherlands, as during the time of Charles V. The inhabitants of the Netherlands were not rebel

62 'Quid enim honestius, quid dulcius, quid utilius amicitia tua? Quo magis indignor tot ultro citroque scriptas epistolas nobis periisse, idque eo maxime tempore quo tua cum auctoritate et consilio, tum fauore et gratia mihi praecipue opus fuit, ob nouam scilicet hanc dignitatem quae cum tuo potissimum studio atque opera delata mihi fuerit.' Torrentius to Montano, 30 June 1588, in M. Delcourt and J. Hoyoux, Laevinus Torrentius: Correspondance, 3 vols (Paris 1950-1954), 2, 250, no. 437.

${ }^{63}$ Copies of twenty-nine letters are preserved in the Royal Library of Belgium in Brussels (Ms. 15704). There are two editions of this correspondence: M. de Ram, Compte rendu des Séances de la Commission Royale d'Histoire, Deuxième série 7 (Brussels 1855), 235-325; and Delcourt and Hoyoux. Recently a modern edition with introducion and translation of the correspondence between Torrentius and Montano appeared: L. Charlo Brea (ed.), Levino Torrencio. Correspondencia con Benito Arias Montano, Palmyrenus. Colección de textos y estudios humanísticos, Serie Textos 20 (Alcañiz-Madrid 2007).

${ }^{64}$ See J. De Landtsheer, 'Benito Arias Montano y sus amigos de su época amberiense', in Benito Arias Montano y los humanistas de su tiempo, Maestre Maestre, Sánchez Salor et al. (eds), 1, 3-25.

${ }_{65}$ Torrentius to Arias Montano, 29 August 1588. See in Delcourt and Hoyoux, Laevinus Torrentius, 2, 312-314, no. 479. 
subjects who, as many Spaniards said, after the war would have the status of a mere province conquered by the King. ${ }^{66}$

Even though Torrentius trusted that the King would follow his advice when Montano showed him his letters, Montano himself did not answer many of them. Nevertheless, he was resigned to not receiving answers as long as his letters came to the hands of the King. But Arias Montano only translated two Latin letters of Torrentius into Spanish and sent them to Madrid. ${ }^{67}$ We do not know the exact reasons for this lack of diligence on Arias Montano's part: besides his other occupations, the old Montano was probably no longer the influential counsellor who had the ear of King Philip as in the past. This lack of correspondence, together with the classic delay with which Philip II made his decisions, seriously taxed Torrentius's patience. He ended and summed up his correspondence to Montano with a sort of political testament, asserting that he had always looked for the Lord's glory and the good of his country. ${ }^{68}$

Next to Plantin and Torrentius, there was a third informant, one ignored by all previous studies: Luis Pérez, a rich merchant from Jewish origins, whose family had settled in Antwerp in the first half of the sixteenth century. The relationship between the Pérez family and Montano still needs to be studied in more detail. He probably knew Luis before his sojourn in Antwerp, for in Seville he had been closely connected to Francisco Núñez Pérez, a member of another branch of the Pérez family. Luis was a close friend of Plantin, to whom he occasionally gave financial support, and soon became Montano's closest friend in the Netherlands. Occasionally he also lent money to King Philip. Two unpublished letters from 1592, sent by Pérez to Montano are still preserved in the Archivo General de Simancas; they expound upon the Revolt offering a sharp analysis of the situation in the Netherlands. ${ }^{69}$ It was Arias who requested these precious reports, as can be deduced from the following passage:

${ }^{66}$ Torrentius to Arias Montano, 3 July 1592. See in Delcourt and Hoyoux, Laevinus Torrentius, 3, 364-368, no. 975.

${ }^{67}$ On 8 February 1590 and 13 October 1594 (in Archivo General de Simancas, Estado 169 and Ms. Stockholm 170, respectively).

${ }_{68}$ Torrentius to Arias Montano, 13 February 1595. See in Delcourt and Hoyoux, Laevinus Torrentius, 3, 610-614, no. 1193.

${ }^{69}$ Letters written on 19 March 1592 (original in Archivo General de Simancas, Estado, 169 /176); and on 3 March 1592 (original Archivo General de Simancas, Estado, 169 /178). Around that same time Montano dedicated to Pérez the commentary 
The return of His Highness's [= Governor Alexander Farnese] with his army will also be a good thing, if what he said last night is true, that he is to come back to the Low Countries after having left in Rouen the military support and the ammunition needed to continue for many months the resistance against Henry of Navarre's army who has put siege to the city. [...] If I acquire more definite information before closing this letter, I shall tell you, to oblige. ${ }^{70}$

And at the end of this same letter, we come to know that Pérez's reports ended up in the King's hands. Arias had recommended his closest friend in the Netherlands as a merchant with a deep philosophical and intellectual formation:

I should have moved just at your command and made myself sure that my loyal, unselfish, and dispassionate advice pleased His Majesty, whose welfare and his people's I desire for the glory of God, to whom we all owe everything.

All scholars involved in the study of Arias Montano's correspondence have wondered where the remaining part of their letters might be found, if still extant. The historical value of Pérez's reports lies beyond all doubt: the influential merchant and banker not only refers to the military affairs of the moment, but he also pays attention to the criticisms, suspicions and accusations (even concerning the king or the pope) voiced by the main ecclesiastical and political members of Antwerp society:

[...] which I deduced from words I heard of clergymen and laymen who shall not dare utter it in any other way. I want to record the words so that you do not suspect they are worse than they are. They criticize His Highness [= Farnese] very much for the four years he tolerated heretics in Antwerp without an army, because they kept their heads down, and two years in Brussels and in Bruges without end. And not only His Highness, but also His Majesty [= King Philip], who approved it, and when I

\footnotetext{
of one Psalm in his In XXXI Davidis psalmos priores commentarii (Antwerp: J. Moretus 1605), 118-119. After Plantin's death, Luis Pérez was the main bond between Montano and the printing house of the Golden Compasses. On Luis Pérez, see Biographie nationale 17 (Brussels 1903), 13-15; Dávila, Benito Arias Montano. Correspondencia, 1, xxv-xxvI; D. Imhof, 'De Spaanse koopman Luys Perez als financier van Jan Moretus' uitgaven van Benedictus Arias Montanus', in De Gulden Passer 83 (2005), 149-155.

${ }^{70}$ Luis Pérez to Arias Montano, 19 March 1592 (original in Archivo General de Simancas, Estado, 169 /176).
} 


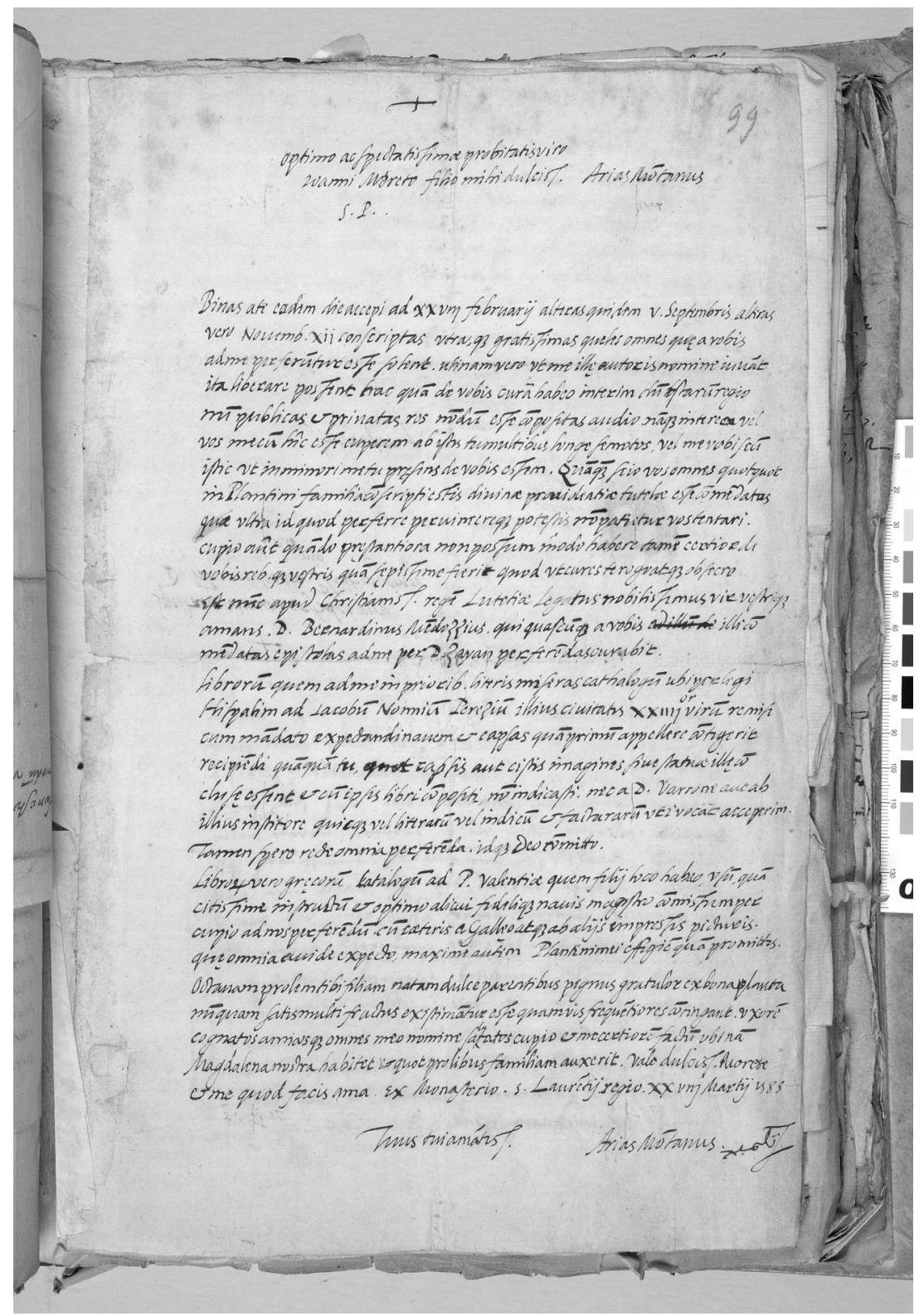

Fig. 12. Benito Arias Montano, Letter to Johannes Moretus (4 May 1592). Antwerp, Museum Plantin-Moretus, Arch. 76, f. 113 
referred this clergyman's talk to our bishop, he said that it involved His Holiness [= Pope Clement VIII] as well, who had approved it. ${ }^{71}$

Now I would like to turn to two more letters from Pérez to Montano. They have been published in the Colección de documentos inéditos para la historia de España as reports written in Spanish in 1577, addressed to Montano by an anonymous Antwerp source not long after Montano's departure from the Netherlands. ${ }^{72}$ Yet there are a number of arguments for identifying the author of these reports as Luis Pérez. Firstly, Montano sent a copy of both of them to the King with the note that they were written by 'a good subject of His Majesty, born in that country'; as we have seen, fifteen years later, Arias Montano continued to send Pérez's reports to Philip II. Secondly, they are written from Antwerp, where Pérez was born and lived, and in Spanish, the family's mother tongue. Thirdly, the unnamed letters of the seventies relate current war news from a pacific perspective, in a way similar to the reports signed by Pérez in the nineties. Unfortunately, since the anonymous reports preserved in Simancas are copies made by Montano, we cannot compare the handwriting of these reports with autograph documents in Pérez's hand, which would provide conclusive evidence. Nevertheless, the style and the language of the anonymous documents seem to be very close to that of the two letters signed by Pérez in the nineties. Among other minor coincidences, the author concludes his message with the same commonplace similary phrased: he apologizes for the extension of his report, but his intention is to serve his Majesty:

Si me $e$ alargado, V[uestra] M[erced] corrija mis faltas y las atribuya a este mi deseo que en esto aspira al servicio de Dios y de $S[u]$ M[ajesta]d. ${ }^{73}$

If I went on too long, you may correct my mistakes and ascribe them to my wish of aspiring to God's and His Majesty's service.

${ }^{71}$ Luis Pérez to Arias Montano, 19 March 1592.

72 Letters written on 23 October and 23 November 1577, published in Correspondencia del Dr. Benito Arias Montano... desde 1568 hasta 1580, Colección de Documentos inéditos $41,354-358$ and 358-362 respectively.

${ }_{73}$ Anonymous letter to Arias Montano, 23 November 1577, in Correspondencia del Dr. Benito Arias Montano...desde 1568 hasta 1580, Colección de Documentos inéditos 41,359 (the italics are mine). 
Y no sé cómo e alargado sin pensar de hazerlo. Deví moverme con mandármelo V[uestra] M[erced] y certificarme que mis avisos leales, claros y desapasionados eran gratos a Su Mag[esta]d. ${ }^{74}$

And I do not know how I went on too long without realizing it. I should have moved on by recommending me to Your Majesty and ensuring myself that my loyal, clear, and dispassionate advice pleased His Majesty.

Although this is just a tiny part of the correspondence exchanged between Montano and Pérez, it allows us to conclude that Luis Pérez was one of Spain's most important informants on the war situation in the Netherlands, considering he must have been sending such letters over a period of more than twenty years. Montano probably refers to him as one of the contacts he had in Antwerp in one of his last testimonies on politics of the Low Countries, from the middle of 1595.

I had many friends and acquaintances [...] and among them I enjoyed credit and confidence [...], while they trusted me more than any other Spaniards [...] and they informed me about what was kept in secrecy among them [...]. Many of these friends and informants have passed away, but I still have some important contacts left who keep trusting me. $^{75}$

The service to his optimus patronus, King Philip, and to his protégés in the Low Countries compelled Montano to engage himself in such political negotia almost until the end of his life. Nevertheless, it is beyond all doubt that, after his departure from Antwerp, his influence on the political theatre of the Netherlands decreased for obvious reasons. Firstly, the geographical distance delayed and limited the value of the political advice about the Revolt he could send to the King: Philip II wanted counsellors in situ, able to observe the situation with their own eyes and offer solutions and advice based on their outstanding intellects and profound experience. Secondly, Arias was much occupied in missions of various duration and importance that kept him far from the political scene. Finally, in the last years of his life he seems to have been too tired and, at the same time, too concentrated on writing his works to dedicate much time to the situation in Neth-

\footnotetext{
${ }^{74}$ Luis Pérez to Arias Montano, 19 March 1592, original in Archivo General de Simancas E 169/176 (the italics are mine).

${ }^{75}$ Letter of Arias Montano, 11 May 1595, in Morales Oliver, Arias Montano y la política, 356-357.
} 
erlands. Nevertheless, the voices of the social elites of the Netherlands, among whom Montano had been able to move freely during his seven years in the Low Countries, still came to the King's ears thanks to the Spanish theologian. Until now, historians were only aware of Torrentius's role as an informer on the political events and how they affected the religious situation. Thanks to Luis Pérez's letters, this can now be completed with the perception of the urban bourgeoisie of the Low Countries, with whom Montano had such close connections too.

\section{Arias Montano's Shipwreck between Scylla and Charybdis}

When Montano arrived in Antwerp as royal commissioner, at the summit of his social recognition, he seemed anxious to take part in the politics of the Low Countries. A careful examination of Montano's correspondence shows that the Spanish humanist wanted to participate actively in the political situation of the Netherlands from the very beginning of his sojourn in Antwerp. In the first letter he wrote to King Philip from Antwerp, dated 6 July 1568, he cautiously suggests him to visit this region in person as the most effective solution to abort new revolutionary attacks. For, to use Montano's words, 'the grace, the threat or the punishment of the father are more effective for the good of the family than anything and anybody else' ${ }^{76}$ Four months later, he offers himself as counsellor of the King in a letter to the royal secretary Gabriel de Zayas. ${ }^{77}$

Montano thus seemed to be anxious of operating as a counsellor for the King, but the huge tasks concerning the Bible made it impossible to develop this function, at least until 1571. Philip II began to request political reports from his Chaplain at the end of 1572, after the conclusion of the Polyglot and Montano's return from the journey to Rome. Yet the new documents studied here prove that, from

\footnotetext{
${ }^{76}$ Arias Montano to Philip II, 6 July 1568, in Carvajal, Elogio histórico, 149 (doc. 26).

77 'Whenever you think I can write to His Majesty you will let me know, because if he is so kind as to let me simply write what I might feel as his good servant and as a Christian who knows some things, partly from having read, partly from what I have taken in over forty-three years of life, most of them travelling, and observation of what I have seen, and communication with people of all sorts, then I, in spite of being nobody in comparison to the many who serve His Majesty in this, shall do it without any other consideration than to serve God, him, and the public welfare.' Letter of 9 November 1568, in Colección de Documentos inéditos 41, 135.
} 
1573 onwards, just when Arias's political influence was at its height, he only hoped to be discharged from his official duties and to retire in order to concentrate on his writings. In view of these facts, it seems to me that two kinds of shifts in Montano's positions on the Revolt of the Netherlands must be examined: the first one belongs to the public context, that is the clear change in his letters to the king from support for Alva's policy to insisting on new methods of pacification for the Netherlands. The second one has to do with the private sphere: something happened in Montano's soul to turn his lively interest to take part in the politics of the Netherlands in 1568, into a request to be discharged from all his public duties in 1573.

According to Rekers, Arias Montano's political shift from a defence of Alva's iron hand to more pacific positions corresponded to a deeper conversion (even spiritual) caused by the principles of the 'Family of Love'. This is not the place to dwell upon the presence or not of this sect in Plantin's circle, but most of the arguments that Rekers has presented in support of the view that Montano, a leader of CounterReformation, belonged to the sect called Familia Caritatis are weak. In my opinion, we need not propose adherence to any sect whatsoever in order to explain the irenic ideology that brought Montano to maintain contacts with Catholics and Protestants, or the preference he expressed for an internal religiosity over the formalism of ceremonies: these ideas simply show the heritage of the Erasmian philosophia Christi that he, and other Spanish humanists, learned at Seville and Alcalá. ${ }^{78}$ As for Plantin, attention should be drawn to the strong evidence presented by Paul Valkema Blouw ${ }^{79}$ that the printer's first contacts with the sect had a mainly commercial aim. As a personal contribution, I studied an incorrect reading that appeared in the Correspondance de Christophe Plantin: ${ }^{80}$ where he wrote 'regards to all the family of Plantin' (omnis familia in the manuscript), the first editor of the text tran-

\footnotetext{
${ }^{78}$ Moreover, Montano did not hide his acquaintance with persons of suspect orthodoxy, but even defended them in his works: in the preface of his Elucidationes in omnia sanctorum apostolorum scripta (Antwerp 1588) he confesses that he began to understand the book of Revelation thanks to the help of a 'Christianae veritatis testis, cui nomen ipsa Christi virtus et veritas Hiel indidit.'

79 'Was Plantin a member of the Family of Love? Notes on his dealings with Hendrik Niclaes', in Quaerendo 23 (1993), 3-23.

${ }^{80}$ Letter from Arias Montano to Christopher Plantin, [11-19] April 1576, in M. Rooses and J. Denucé, Correspondance de Christophe Plantin, 8 vols (Antwerp 18831918), 4, 296.
} 
scribed 'regards to the family of Love' (amoris familia). ${ }^{81}$ Subsequent literature, not only by Rekers, which portrays Plantin and Montano as adherents of that sect, has been based on erroneous readings such as this and-as Jeanine De Landtsheer explains ${ }^{82}$-on a narrow interpretation of the Latin familia as 'belonging to the Family of Love' instead of its classical meaning 'a group of people closely connected'.

It seems to me that we have to put other private and public arguments forward to explain why Montano changed his political positions so strongly from the period of Alva's government to that of Requesens. As far as the public situation was concerned, the political context also changed considerably from 1568 to 1572: at the beginning, after the iconoclastic fury, Alva's toughness was justified, but later on peaceful measures were more appropriate. When Montano wrote reports favouring a paternal policy in opposition to Alva's hard regime in 1573, he was doing the same as other counsellors from the Netherlands, such as Joachim Hopperus, Stephen Praets and even Juan de la Cerda, duke of Medinaceli, who are not thought to belong to any sect. The correspondence preserved by the House of Alva shows that there was no breach in the relationship between Montano and the governor, and, as mentioned before, we even find words of complete submission to Alva in letters from Montano as late as 1573.

As for the private circumstances, Montano's shift from an interest in politics to the request for retirement has not been studied yet. It seems to me that the most important matter to explain this change is the sense of frustration (let us call it personal shipwreck) the humanist experienced at the end of 1572. The two official tasks he undertook for the King were not as successful as the humanist had hoped. As regards the Bible, the negative reactions came not only from the Calvinist front, but also from the Catholic: Arias had to make the fullest use of his diplomatic means to get Rome's approval of the Polyglot. ${ }^{83}$ Besides, two persecutors severely attacked the orthodoxy of this Bible for years:

\footnotetext{
${ }^{81}$ See my article 'Dos lecturas erróneas (omnis familia / amoris familia y simque/ sinque). Consecuencias en la bio-bibliografía de Arias Montano (1527-1598) y de la imprenta plantiniana', in Lias 30 (2003), 299-309.

${ }_{82}$ De Landtsheer, 'Benito Arias Montano y sus amigos de su época amberiense', 24. She is also preparing an article proving that Rekers, among others, was wrong in considering Arias Montano a member of the Family of Love.

${ }^{83}$ On the Biblia Regia and the polemics that arose from it, see B. Macías Rosendo, La Biblia políglota de Amberes en la correspondencia de Benito Arias Montano (Ms. Estoc. A 902) (Huelva 1998).
} 
the Salamanca theologian León de Castro in Spain, and the Bishop of Roermond, Guilielmus Lindanus, in the Low Countries. ${ }^{84}$ Even the Expurgatory Index of 1571 was criticized in Rome. Montano's middle position in the field of biblical philology did not satisfy anybody. This shipwreck upon the cliff of Charybdis (i.e., religion) surely caused a deep frustration.

But Montano was also shipwrecked on the cliff of Scylla (i.e., politics). Regarding his role as unofficial ambassador of the king, let us remember the deep pain he felt at the ruinous state of the Netherlands when he came back from Rome, at the end of 1572. At that moment Montano, like many Spaniards, including King Philip, understood that severity was not an appropriate way to pacify the Netherlands. After four years in Antwerp, his distress and his political arguments were also motivated by the huge number of local acquaintances from various social circles he considered protégés. In 1573, when the King gave him a more prominent role as unofficial counsellor, many people doubted that a scholar like Arias Montano had the necessary political insight. For instance, Maximilian Morillon, vicar-general of Cardinal Granvelle, was clearly opposed to the actions of the Spanish counsellor. The correspondence between Morillon and Granvelle includes several passages extremely critical of the political decisions inspired by Montano. With regard to the statue of Alva (cf. supra, n. 15) and the negative reaction it caused among the inhabitants of the Low Countries, Morillon writes: 'For this foolishness I blame Montano, who committed it, rather than Alva. ${ }^{85}$ A few days later, on 19 July 1574, Morillon criticized the excessive influence of Montano on the new governor Luis de Requesens: 'I believe he receives fewer dispatches from the King than Arias, which makes many laugh, ${ }^{, 86}$ and: '[...] He governs the governor easily, and receives more letters and packets from the King

${ }^{84}$ See my article 'La polémica Arias Montano-Wilhelmus Lindanus: un nuevo documento (AGR I 115, no 3714)', in Humanistica Lovaniensia 49 (2000), 139-165.

${ }_{85}$ 'J'impute plus cette foly a celluy qui l'a feit, que fust Arias, qu'a luy', Morillon to Granvelle, 14 June 1574, in E. Poullet and C. Piot, Correspondance du Cardinal de Granvelle, 1565-1586, 12 vols (Brussels 1877-1896), 5, 138; text quoted by Morales Oliver, Arias Montano y la política, 143.

${ }^{86}$ Morillon to Granvelle, 19 July 1574, in Poullet and Piot, Correspondance du Cardinal de Granvelle, 5, 165. Text quoted in Morales Oliver, Arias Montano y la política, 293-294. 
than the Commander. ${ }^{97}$ Morillon voiced even harsher criticism, that Montano was arrogant:

He has boasted he shall clean the whole country of heresies in four months: please God they were as many years! He is not the man [for this task], and those who carefully leaf through his Bible consider it unworthy of being mentioned frequently. ${ }^{88}$

In order to understand the political movements of Montano regarding the Revolt of the Netherlands, we must consider the internal tension between, on the one hand, his request for retirement-in my opinion due to those failures in political and religious matters explained above-and, on the other hand, his acute skill in taking part in human negotia. On his social promotion from his humble origins in Fregenal (Extremadura) to his appointment as an unofficial ambassador of the Spanish Crown, a recent study by Guy Lazure ${ }^{89}$ outlining the unwritten rules of the complex system of patronage and the dynamics of favour and obligation that system implied, makes essential reading. From his earliest youth, Montano showed a great talent for recognizing and obtaining the favour of the men whose influence could help him in his personal aspirations. During his stay in the Netherlands, he rendered services to the most powerful patronus of the period, King Philip, but, as we have seen, he also managed to get the sympathy and favour of the two Governors General, Alva and Requesens, through their confidants Juan de Albornoz and Juan de Zúñiga, respectively. Montano even knew how to keep the powerful influence of Alva, although his reports to the king were opposed to the policy of the governor. Besides, Montano always mixed easily in the leading political, ecclesiastical, intellectual and economic circles of the Netherlands. ${ }^{90}$ This explains why the king appreciated his counsellor's advice

${ }^{87}$ Morillon to Granvelle, September 1574, in Poullet and Piot, Correspondance $d u$ Cardinal de Granvelle, 5, 236. Text quoted in Morales Oliver, Arias Montano y la política, 293-294.

${ }_{88}$ Morillon to Granvelle, 19 July 1574, in Poullet and Piot, Correspondance de Granvelle, 5, 165. Text quoted in Morales Oliver, Arias Montano y la política, 295.

89 'Mecenazgo y clientelismo en los años sevillanos de Benito Arias Montano. Genealogía social e intelectual de un humanista', in Benito Arias Montano y los humanistas de su tiempo, Maestre Maestre, Sánchez Salor, et al. (eds), 1, 111-124. See also Lazure's doctoral dissertation, 'To Dare Fame: Constructing a Cultural Elite in Sixteenth Century Seville' (Baltimore, MD, March 2003).

${ }_{90}$ 'In conversations, secrectly and in public, the locals dare to declare their concepts, imaginations, and suspicions in front of me as a dispassionate and quiet person, which they do with few of our nation, and so I can say some things which are not 
so much. It was precisely because of his willingness to serve the king and to oblige the friends he patronized among the upper class of the Netherlands that Montano remained caught in the bustle of politics to the end of his life, in spite of his want for total calm.

revealed to others.' Arias Montano to Gabriel de Zayas, without date, in Correspondencia del Dr. Benito Arias Montano... desde 1568 hasta 1580, Colección de Documentos inéditos 37, 90. 